\title{
Investigating temperature breaks in the summer fruit export cold chain: A case study
}

\begin{tabular}{|c|c|}
\hline \multicolumn{2}{|c|}{$\begin{array}{l}\text { Authors: } \\
\text { Heinrich W. Freiboth } \\
\text { Leila L. Goedhals-Gerb } \\
\text { F. Esbeth van Dyk }{ }^{2} \\
\text { Malcolm C. Dodd }{ }^{3}\end{array}$} \\
\hline \multicolumn{2}{|c|}{$\begin{array}{l}\text { Affiliations: } \\
{ }^{1} \text { Department of Logistics, } \\
\text { Stellenbosch University, } \\
\text { South Africa }\end{array}$} \\
\hline \multicolumn{2}{|c|}{$\begin{array}{l}{ }^{2} \text { CSIR Built Environment, } \\
\text { South Africa }\end{array}$} \\
\hline \multicolumn{2}{|c|}{$\begin{array}{l}{ }^{3} \text { Department of Horticultural } \\
\text { Science, Stellenbosch } \\
\text { University, South Africa }\end{array}$} \\
\hline \multicolumn{2}{|c|}{$\begin{array}{l}\text { Correspondence to: } \\
\text { Esbeth van Dyk }\end{array}$} \\
\hline \multicolumn{2}{|c|}{$\begin{array}{l}\text { Email: } \\
\text { fevandyk@csir.co.za }\end{array}$} \\
\hline \multicolumn{2}{|c|}{$\begin{array}{l}\text { Postal address: } \\
\text { PO Box 320, Stellenbosch } \\
7599, \text { South Africa }\end{array}$} \\
\hline \multicolumn{2}{|c|}{$\begin{array}{l}\text { Dates: } \\
\text { Received: } 27 \text { Mar. } 2013 \\
\text { Accepted: } 22 \text { Aug. } 2013 \\
\text { Published: } 07 \text { Nov. } 2013\end{array}$} \\
\hline \multicolumn{2}{|c|}{$\begin{array}{l}\text { How to cite this article: } \\
\text { Freiboth, H.W., Goedhals- } \\
\text { Gerber, L.L., Van Dyk, } \\
\text { F.E. \& Dodd, M.C., 2013, } \\
\text { 'Investigating temperature } \\
\text { breaks in the summer } \\
\text { fruit export cold chain: } \\
\text { A case study', Journal of } \\
\text { Transport and Supply Chain } \\
\text { Management 7(1), Art. } \\
\text { \#99, } 7 \text { pages. http://dx.doi. } \\
\text { org/10.4102/jtscm.v7i1.99 }\end{array}$} \\
\hline \multicolumn{2}{|c|}{$\begin{array}{l}\text { Copyright: } \\
\text { (C) 2013. The Authors. } \\
\text { Licensee: AOSIS } \\
\text { OpenJournals. This work } \\
\text { is licensed under the } \\
\text { Creative Commons } \\
\text { Attribution License. }\end{array}$} \\
\hline \multicolumn{2}{|l|}{ Read online: } \\
\hline 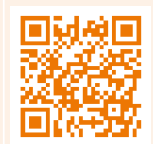 & $\begin{array}{l}\text { Scan this QR } \\
\text { code with your } \\
\text { smart phone or } \\
\text { mobile device } \\
\text { to read online. }\end{array}$ \\
\hline
\end{tabular}

There is concern in the South African fruit industry that a large amount of fruit and money is lost every season due to breaks in the fruit export cold chain. The possibility of a large percentage of losses in a significant sector of the economy warranted further investigation. This article attempted to highlight some of the possible problem areas in the cold chain, from the cold store to the port, by analysing historic temperature data from different fruit export supply chains of apples, pears and grapes. In addition, a trial shipment of apples was used to investigate temperature variation between different pallets in the same container. This research has added value to the South African fruit industry by identifying the need to improve operational procedures in the cold chain.

\section{Introduction}

The South African fruit industry is a significant employment generator; it employs approximately 460000 people who have two million dependents (Van Dyk 2011). Furthermore, fruit exports account for $50 \%$ of all agricultural exports in South Africa, with an export value of approximately R12 billion (Kruger 2013). Unfortunately, there is a growing concern in the South African fruit industry that a large amount of fruit and money is lost every season. This is thought to be mainly due to a loss of fruit quality as a result of breaks in the cold chain. The possibility of a large percentage of losses in such a significant sector of the economy warrants further investigation.

A typical fruit export cold chain starts at the point of harvest on the farm (as illustrated in Figure 1). The freshly picked fruit is moved to a refrigerated room in order to remove any remaining field heat; this is called the pre-cooling process. In order to preserve the quality of the fruit, it is important to remove field heat as soon as possible after the fruit has been harvested.

Grapes are usually packed on the farm and then transported to a regional cold store for forced cooling in order to reduce the fruit pulp temperature to $-0.5^{\circ} \mathrm{C}$. The grapes are then put in cold storage, where the pulp temperature is maintained at $-0.5{ }^{\circ} \mathrm{C}$. The cold chain for grapes will typically begin on the farm where they are pre-cooled to remove field heat. Apples and pears have a longer shelf life than grapes and can be held in cold storage for longer periods, depending on market conditions. Freshly harvested apples and pears are typically transferred to a regional pack house and cold store, they are then force-cooled and stored in cold rooms for a period of time before they are packed for export. Since apples and pears have already been refrigerated by the time they are packed, it is important to examine the apple and pear export cold chain from the cooling section before the pack house and beyond.

Once pre-cooled, the fruit is transferred to the pack house for sorting and packaging. After the packaging stage, the fruit is transferred to a cold store for storage under refrigerated conditions until the export date arrives. The fruit is then transported to the port for export to the destination market where it will be offered to the consumer. If the duration of the road transport segment from the pack house to the port of export exceeds two hours, the Perishable Product Export Control Board (PPECB) prescribes the use of refrigerated (reefer) containers or refrigerated trucks (The Perishable Products Export Control Board 2013:4-22). A reefer container has its own refrigeration system and requires a power source with which to operate. A generator set (commonly known as a genset) can be attached to the reefer container during transit in order to deliver power to the refrigeration system. However, reefer containers, refrigerated trucks, and gensets are not designed to cool the fruit, but rather to maintain the temperature of fruit that has been pre-cooled and stored in a cold store prior to loading (The Perishable Products Export Control Board 2013:4-19).

Even though the fruit is transported in a reefer container or refrigerated truck, the container or truck should not be cooled prior to loading, unless an airlock is used at the loading bay. This is to reduce the risk of container rain, which occurs when warm air outside the container 


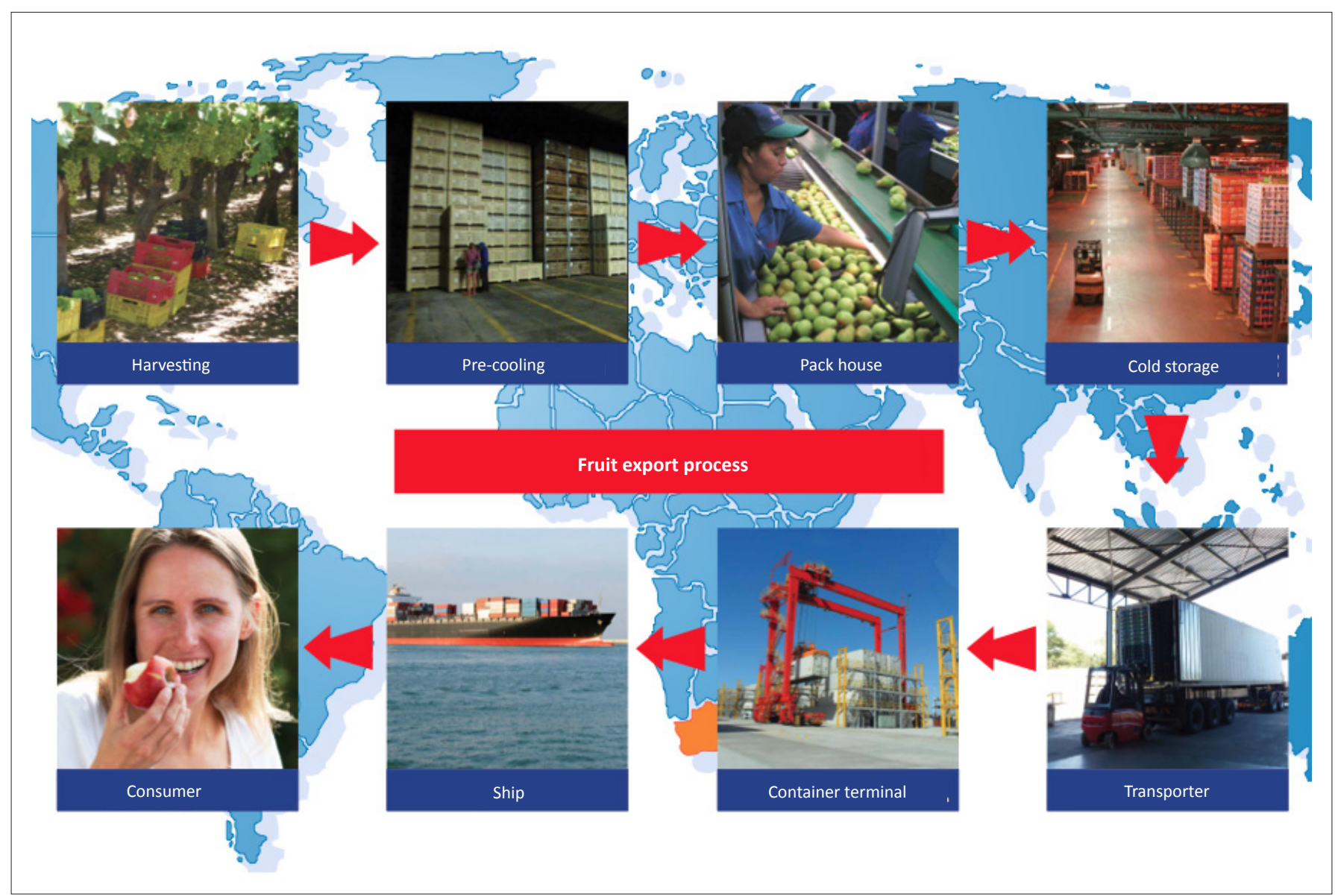

Source: Dodd, M.C. \& Van Dyk, F.E., 2013, Analysis of temperature breaks in the fresh fruit export cold chain from South Africa, poster for Post-Harvest Innovation Programme exhibition, Century City FIGURE 1: Diagram of a typical fruit export process.

causes moisture to condensate on the roof and walls of the cooled container as soon as the container doors are opened for loading. The moisture that subsequently 'rains' onto the fruit can cause considerable damage, especially in the case of grapes.

Refrigerated containers are stacked in a reefer container yard, an area in the port that is equipped with electrical power points that supply reefer containers with electricity. To minimise the time that the refrigeration unit is without power it is very important that a container should be plugged in as quickly as possible once it is in the stack. Containers are usually stacked according to the sailing schedule and loading plan of the vessel they will be exported on. The containers are kept in the reefer yard until the vessel is ready to be loaded. Once loaded on board the vessel, the containers are plugged into the vessel's electrical power supply.

Any break in the cold chain will cause the ripening process to resume, resulting in a loss of quality or total loss of the product. According to Thompson (2002) any rise in temperature above the product-appropriate set point (the optimum temperature at which the product must be kept during transit) will result in a lowering of the quality of the product. The longer the length of the break and the higher the peak temperatures that are reached, the more severe the reduction in quality. Furthermore, cold chain breaks are additive in nature and several small breaks can have the same negative effect on fruit quality as one large break.

\section{Literature review}

The concern about fruit loss due to breaks in the cold chain is supported by studies that have been conducted in several countries. A study in India found that approximately $30 \%$ of fruits and vegetables harvested in the country are lost annually due to breaks in the cold chain. This leads to unstable prices for the local farmers and uncompetitive prices and costs when compared to other countries (Maheshwar \& Chanakwa 2006).

A study by the University of KwaZulu-Natal found that the quality of avocados is severely affected by breaking the cold chain. The results of this study estimated that $80 \%$ of fruit stored at the appropriate temperature without a break in the cold chain maintained its quality, whilst only $31 \%-60 \%$ of fruit that had a cold chain break achieved the same quality levels (Blakey, Bower \& Bertling 2011).

All perishable products have a finite lifespan and are in a state of decline from the moment of harvest. According to Thompson et al. (2008:1), temperature is the greatest determinant of fresh- produce deterioration rates and potential market life. Cooling specifically minimises water loss, slows down decay by reducing the growth of fungi 
and reduces the rate of perspiration by the fruit (Ngcobo 2008). This prolongs shelf life and maintains the quality and freshness of the product during the export process. However, it is crucial to remember that cold chain logistics can only preserve, not improve, the quality of perishable products.

Table grapes, for example, are a highly perishable commodity and the storage conditions need to be managed very precisely to ensure good quality in the market place. The quality of uncooled grapes deteriorates more in one hour at $32{ }^{\circ} \mathrm{C}$ than in one day at $4{ }^{\circ} \mathrm{C}$, or even a full week at $0{ }^{\circ} \mathrm{C}$ (Thompson et al. 2008). The main physiological defects that afflict table grapes are browning of stems, drying of stems, shrivelling (weight loss) of berries and berry softening (Nelson 1985; Crisosto et al. 2001). These disorders are controlled by reducing the temperature of the grapes from field temperature to $0{ }^{\circ} \mathrm{C}$ as quickly as possible after harvest. Thereafter, it is vital to keep the grapes as close to $0{ }^{\circ} \mathrm{C}$ as possible for the entire length of the supply chain. Stable, low temperatures and a high relative humidity will reduce the incidence of the aforementioned disorders.

Table grapes are also very susceptible to infection by a fungus Botrytis cinerea. This fungus causes a grey mould to grow on the grapes and renders them unsuitable for marketing and consumption. To control this fungus, the storage temperature must be kept constantly at $0{ }^{\circ} \mathrm{C}$ and sulphur dioxide sheets must be packed with the grapes (Nelson 1985). The sulphur dioxide emitted by these sheets inhibits the growth of the grapes. If the storage temperature rises above $0{ }^{\circ} \mathrm{C}$ the amount of sulphur dioxide emitted increases; this higher concentration will cause a bleaching of the skin, particularly of dark-skinned grapes. It is therefore vital to maintain the cold chain at $0{ }^{\circ} \mathrm{C}$ along the entire length of the grape supply chain

Eliminating losses completely might not be economical or feasible, but lowering post-harvest losses to acceptable levels should be a global priority. Kader (2005:2170) proposed that acceptable levels of post-harvest losses should be identified according to commodities, seasons and production regions within a fruit industry through the use of cost-benefit analysis.

The PPECB governs the export of perishable products through South Africa's ports on behalf of the Department of Agriculture, Forestry and Fisheries and has protocols and procedures in place to ensure optimum cold chain operations. The PPECB's protocols and procedural guidelines are published annually in their Blue Book; it contains important guidelines for the handling, storage and transportation of perishable products, with specific emphasis on the optimum temperature of each product. The optimum product or pulp temperature prescribed for apples, pears and grapes is $-0.5^{\circ} \mathrm{C}$ for the duration of the cold-chain journey (The Perishable Product Export Control Board 2012:8-10).

Yet, losses do still occur. There is a definite lack of studies regarding the specific causes of the loss of fruit in South
Africa and accurate accounts of the extent of these losses. This article endeavours to contribute to this gap in the research.

\section{Research strategy Research approach}

The main focus and objective of this study was to identify the potential problem areas that are responsible for breaks in the South African fruit export cold chain. This was achieved by analysing temperature and duration for the various stages of the fruit export supply chain from the pack house to the vessel, with the focus being on fruit exported in refrigerated (reefer) containers.

This article examined the fruit export supply chain from the pack house to the port of export. What happens on the farm during the growing and picking stages also plays an important role in the final quality of the product, but this study specifically focused on investigating breaks in the cold chain. Therefore, the investigation only started at the point of refrigeration.

Two main segments between the cold store and the port of export were identified. These were: segment 1 , which is the initial transport leg from the cold store to the port; and segment 2, which is the time spent in the port until the fruit is loaded onto the vessel for export. Segment 1 was examined in order to determine the time it takes for the fruit to move from the cold store to the port. Segment 2 was examined in order to determine the average amount of time that a container spends inside the port. Most importantly, the temperature in these two sections was examined to determine whether there are any considerable temperature breaks.

\section{Participants}

Since collecting data from every single exporter in the fruit industry fell beyond the scope of this study, the research was based on data from four of the ten largest fruit exporting companies in South Africa, who agreed to participate in the study. The purpose of this study was not to address specific problems that are inherent to any individual company's supply chains, or to infer that the results are representative of the entire South African fruit industry. However, certain common problems can be expected to be prevalent across all fruit export cold chains. Therefore, the sample of supply chains that was investigated is sufficient to identify the potential problems areas in the two identified local segments of the fruit export cold chain.

Retrieving data from overseas receivers can be problematic especially in terms of language barriers when the shipment is destined for regions such as the Far East or Russia. This study's main focus was on the South Africa-to-Europe fruit export supply chain, as this is the most accessible region in terms of retrieving the temperature data and getting comprehensive quality reports.

\section{Measuring instruments or methods of data gathering}

The PPECB requires at least two-hourly readings of the ambient air temperature inside the container during the 
loading and transportation segments of the fruit export supply chain (The Perishable Products Export Control Board 2013:4-6). The temperature inside the container is recorded using temperature monitoring devices (commonly known as loggers) such as TempTale ${ }^{\circledR}$ monitors (Sensitech, USA), or iButtons ${ }^{\circledR}$ (Maxim Integrated, USA), which record the ambient temperature in a container at pre-set intervals for the duration of the shipment. The loggers are inserted into a carton of fruit, usually in the pallet closest to the door, just before the container is sealed. Once the container is opened at the final destination, the data is captured either by manually downloading it from the device, or via radiofrequency identification (RFID) technology, and is then sent to the exporter.

Specialised loggers that record relative humidity and core fruit pulp temperature are also available. These types of loggers are considerably more expensive than the normal ambient temperature loggers and are not required in most markets, including Europe and The United Kingdom. As a result, they are not inserted into containers unless the intended market destination specifically requires that they are to be used in addition to the ambient temperature loggers.

Some importers only send the temperature information and the quality report of a shipment that involved a quality claim if the exporter specifically requires the information for their own records. As a result, most of the available historic data is for ambient air temperature of shipments that resulted in claims. This study mainly examined historic temperature data from past export seasons. However, a trial shipment of apples - containing both ambient and core fruit pulp temperature loggers - was also preformed in order to specifically investigate the difference between the ambient and the fruit pulp temperature inside a refrigerated container.

By adding location information to the temperature timeseries, the different sections of the fruit export supply chain could then be analysed in order to determine in which sections the breaks occurred. The location information used in this study was supplied by the participating fruit export companies.

Historic temperature data were collected and analysed for fruit export supply chains of apples, pears and grapes. The fruit types were influenced by the availability of data and seasonal constraints.

Dataset 1 was an export supply chain for grapes exported from the Orange River Region through the Port of Cape
Town to Europe. The data analysed were from the 2010/2011 grape season. The distance from the cold store to the port is approximately $1000 \mathrm{~km}$, making it the longest road transport segment of the supply chains included in this study. All shipments in this supply chain use either refrigerated trailers or reefer containers with gensets during the road transport segment, in accordance with the PPECB protocols.

Dataset 2 was divided into two subsections: apples and pears, and grapes. The fruit is sourced from various production regions around the Western Cape and loaded into containers, either at the regional cold store of the production region or at consolidation cold stores around the Port of Cape Town, from where it is exported to Europe. The distances from the cold stores to the port vary across the sample. The data analysed were from the 2009/2012 apple seasons and from the $2008 / 2009,2010 / 2011$ and 2011/2012 grape seasons.

Dataset 3 is similar to Dataset 2, as both contain apples and pears, the fruit is loaded at various locations and the exact distances from the cold stores to the port are unknown. The data analysed were for fruit exported between April 2012 and July 2012.

\section{Statistical analysis and treatment of the data}

In order to analyse the temperature data, it was necessary to define what qualifies as a cold chain break. Several people both scientists and people from industry - were consulted on this matter. From a scientific perspective, the optimum air temperature inside a refrigerated container should not exceed $1.5^{\circ} \mathrm{C}$ above the refrigeration set point, otherwise fruit quality might be compromised (Dodd 2012). From a practical perspective, this is not always realistic. Temperature alone is not the only factor that needs to be taken into account when defining a break in the cold chain - the amount of time the temperature rises above the limit also plays an important role in fruit quality.

A compromise between the strict scientific criteria and what is seen as acceptable by the fruit industry was finally chosen. For the purpose of analysing the temperature data in this study, a break in the cold chain was defined as any rise in temperature above $2{ }^{\circ} \mathrm{C}$, for longer than $90 \mathrm{~min}$.

\section{Results and Discussion}

The historic data was analysed to identify any significant trends. Table 1 provides a summary of the historic data collected from each of the supply chains, it includes: the sample size; the average duration of the transport segment; the average duration of the port segment; and the average total duration from the cold store to the vessel.

TABLE 1: Average duration of transit from the cold store to the vessel.

\begin{tabular}{|c|c|c|c|c|c|}
\hline Supply chain & Type of fruit & $\begin{array}{l}\text { Sample size } \\
\text { (containers) }\end{array}$ & $\begin{array}{l}\text { Average duration of transport } \\
\text { segment (hours) }\end{array}$ & $\begin{array}{l}\text { Average duration of port } \\
\text { segment (hours) }\end{array}$ & $\begin{array}{l}\text { Average total duration from the } \\
\text { cold store to the vessel (hours) }\end{array}$ \\
\hline Dataset 1 & Grapes & 108 & 24.895 & 71.317 & 96.212 \\
\hline Dataset 2 & Apples and pears & 30 & 6.033 & 94.867 & 100.900 \\
\hline Dataset 3 & Apples and pears & 28 & 2.607 & 80.000 & 82.607 \\
\hline
\end{tabular}


Firstly, the average duration of the cold chain segments was analysed. It was difficult to compare the duration of transport for the individual supply chains as the exact distances from cold stores to port were unkown. However, it is interesting to note that the average duration of the port segment for grape supply chains appears to be less than that of apples and pears. The average duration of the port segment for grapes was almost identical for Dataset 1 and Dataset 2 (grapes): $71.317 \mathrm{~h}$ and $72.800 \mathrm{~h}$ respectively. On the other hand, the average duration for the apple and pear supply chains was $94.867 \mathrm{~h}$ for Dataset 2 (apples and pears) and $80 \mathrm{~h}$ for Dataset 3. According to Strydom (2010), this could be explained by the higher volume of grape containers that are loaded directly onto the vessel after the stack has been closed. This effectively bypasses the reefer stack and thus reduces the average duration of the port segment.

Secondly, the historic data revealed that the majority of cold chain breaks were observed in the port segments. Table 2 shows the percentage of cold chain breaks experienced in each of the two segments that were investigated. On average, $65 \%$ of the containers sampled across the different supply chains experienced a break during the port segment, whilst $8 \%$ of the containers experienced a break during the transport segment.

Dataset 1 was the only supply chain in which breaks were observed during the transport segment. A possible explanation for this might be that there was a higher ambient temperature inside the containers at the time of loading in Dataset 1 . The average ambient temperature at the time of loading was $10.721{ }^{\circ} \mathrm{C}$ in Dataset 1 , compared to $5.108{ }^{\circ} \mathrm{C}$ and $2.344{ }^{\circ} \mathrm{C}$ in Dataset 2 and 3, respectively. As a result, the ambient temperature inside the containers in Dataset 1 took significantly longer to decrease below $2{ }^{\circ} \mathrm{C}$, even though all shipments in this supply chain used either refrigerated trailers or reefer containers with gensets.

The third important finding is that $60 \%$ of all breaks identified in the historic data occurred between 08:00 and 17:00. Almost a quarter of all breaks occurred between 12:00 and 15:00, which also happens to be the hottest time of the day. This is quite worrying, since the effect of a break in the cold chain during this time of the day would be much more pronounced than if the break occurred during any other time.

As mentioned previously, a trial shipment of apples was performed in order to investigate the difference between the ambient and the fruit pulp temperature inside a refrigerated container. Since the distance from the cold store in the Ceres- region to the Port of Cape Town is approximately $140 \mathrm{~km}$, all containers in this supply chain are equipped with gensets for the duration of the road transport segment.

Ambient temperature loggers were inserted into four of the twenty pallets that were inside the same container in order to investigate temperature variation between different pallets. The four ambient temperature loggers were inserted into pallets 1, 7, 13 and 19 (as illustrated in Figure 2). Pallets 1 and 2 were the pallets closest to the refrigeration unit and the first to receive delivery of the refrigerated air. Pallets 19 and 20 were at the door-end of the container, therefore the furthest away from the refrigeration unit.

Two additional loggers with probes that record fruit pulp temperature were inserted into pallets 1 and 19 . The probe loggers were used to investigate how the fruit pulp temperature responds to fluctuations in the ambient container temperature when breaks in the cold chain occur.

The duration of the transport to the port was $3.733 \mathrm{~h}$, whilst the duration of the port segment was $43 \mathrm{~h}$. These are considerably less than the durations found in the historic data, especially the durations of the port segment. A possible explanation for the shorter durations could be the time of the year during which this trial took place. Since this trial took place at the end of August, and not during the peak apple-export season, relatively low volumes of fruit were being exported at the time. The container could therefore be loaded and transported to the port at a date closer to the stack closing date. This would not have been the case during the peak export season when congestion at the port entrance gate and other possible delays have to be taken into account.

Table 3 shows the average ambient temperatures measured inside the container for the transport and port segments. The ambient temperatures were clearly lower for the pallets closest to the refrigeration unit than for the pallets closer to the door.

Figure 3 shows the ambient temperatures for each pallet as the container moved from the cold store to the vessel. The

TABLE 2: Summary of cold chain breaks per segment and time of day.

\begin{tabular}{llll}
\hline Supply chain & Transport (\%) & Port (\%) & Time of day \\
\hline Dataset 1 & 24 & 85 & $11: 00-15: 00$ \\
$\begin{array}{l}\text { Dataset 2 } \\
\text { (Apples and pears) }\end{array}$ & 0 & 63 & $02: 00-08: 00$ and 15:00-19:00 \\
$\begin{array}{l}\text { Dataset 2 } \\
\text { (Grapes) }\end{array}$ & 0 & 50 & $10: 00-12: 00$ and 15:00-17:00 \\
Dataset 3 & 0 & 61 & $16: 00-20: 00$ \\
\hline
\end{tabular}

\begin{tabular}{|c|c|c|c|c|c|c|c|c|c|c|}
\hline & Pallet 2 & Pallet 4 & Pallet 6 & Pallet 8 & Pallet 10 & Pallet 12 & Pallet 14 & Pallet 16 & Pallet 18 & Pallet 20 \\
\hline & Pallet 1 & Pallet 3 & Pallet 5 & Pallet 7 & Pallet 9 & Pallet 11 & Pallet 13 & Pallet 15 & Pallet 17 & Pallet 19 \\
\hline
\end{tabular}

FIGURE 2: Pallet placement inside reefer container. 
first 'event' symbol indicates the time of departure from the cold store to the port. The second 'event' symbol indicates the time of arrival at the port. The third and fourth dots indicate the time at which the container was loaded onto the vessel, and the time at which the vessel departed from the port, respectively.

As to be expected, the ambient temperature was at a higher level when the pallets were loaded into the unrefrigerated container. The temperature decreased to approximately $2{ }^{\circ} \mathrm{C}$ after $4 \mathrm{~h}$ and $5 \mathrm{~min}$, followed by a slight delay when the container reached the port (second 'event' symbol). Once the container was plugged into the stack, the ambient temperature once again continued to decrease. The increase in temperature towards the end of the graph is an indication that the container had been removed from the stack to be loaded onto the vessel.

The graph clearly illustrates the variation in ambient temperature around the four pallets. Pallet 19 consistently has the highest readings throughout the graph, followed by pallet 13. It can also be seen that the ambient temperature for pallets 1 and 7 are very evenly matched. The difference in the average ambient temperature between pallet 1 and pallet 19 , throughout the entire journey, was approximately $0.67{ }^{\circ} \mathrm{C}$. During the transport segment from the cold store to the port, the average ambient temperature for pallets 1 and 19 differed by more than $1{ }^{\circ} \mathrm{C}$.

Figure 4 compares the average ambient temperature and the core fruit pulp temperature. The orange dots again provide an indication as to when the container left the cold store, arrived at the port, was loaded onto the vessel and when the vessel departed.

Figure 4 clearly illustrates the difference between the ambient temperature inside a container and the actual pulp temperature of the fruit. The average ambient temperature exhibits the same trend as shown by the four separate ambient temperatures of each pallet. However, the core fruit pulp temperature exhibits a different trend. Since the pallets of fruit had just been removed from the cold store at the time of loading, the fruit pulp temperature measurement started off at $-0.5{ }^{\circ} \mathrm{C}$. By the time the probe was inserted and the pallets had been loaded into the container, the pulp temperature had already risen to $0.7^{\circ} \mathrm{C}$ in the space of approximately one hour.

The pulp temperature continued to rise during the transport segment, whilst the ambient temperature decreased. The pulp temperature reached a high of $1.8^{\circ} \mathrm{C}$ when the container reached the port, and then started to decrease as soon as the container was plugged in at the stack. The fruit pulp temperature continued to decrease to $-0.1{ }^{\circ} \mathrm{C}$, before rising again as the container was unplugged to be loaded onto the vessel.

The change in fruit pulp temperature clearly lags behind the change in ambient temperature, this is due to the change in the respiration rate of the fruit with a change in ambient temperature. The average ambient temperature within
TABLE 3: Average temperature during different segments of the cold chain ( $\left.{ }^{\circ} \mathrm{C}\right)$.

\begin{tabular}{lllll}
\hline Cold chain segment & Pallet 1 & Pallet 7 & Pallet 13 & Pallet 19 \\
\hline Average: Transport & 2.950 & 2.628 & 3.253 & 4.028 \\
Average: Port & -0.586 & -0.592 & -0.303 & -0.026 \\
Vessel: Until departure & -0.667 & -0.663 & -0.318 & -0.034 \\
\hline
\end{tabular}

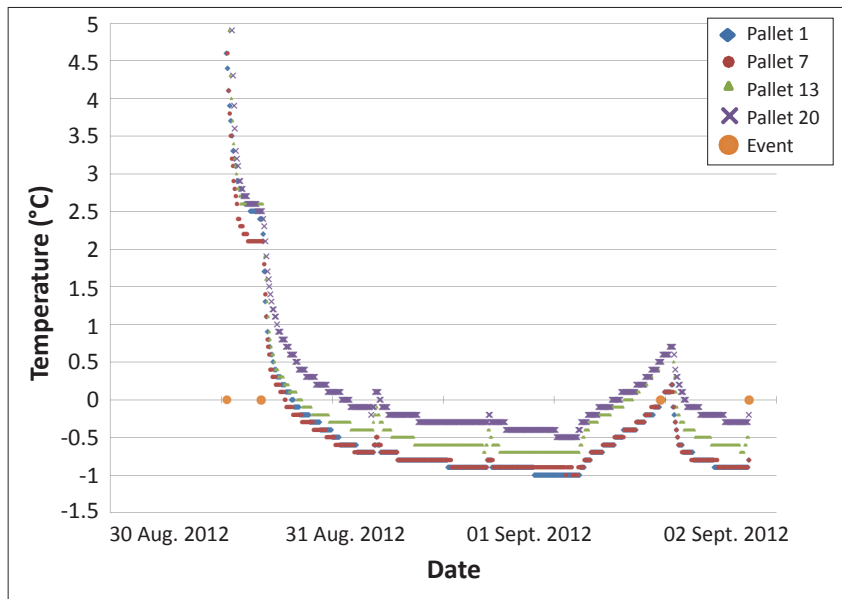

Note: Temperature measured every 12 hours between 30 August 2012 and 02 September 2012.

FIGURE 3: Ambient temperature from the cold store to the vessel.

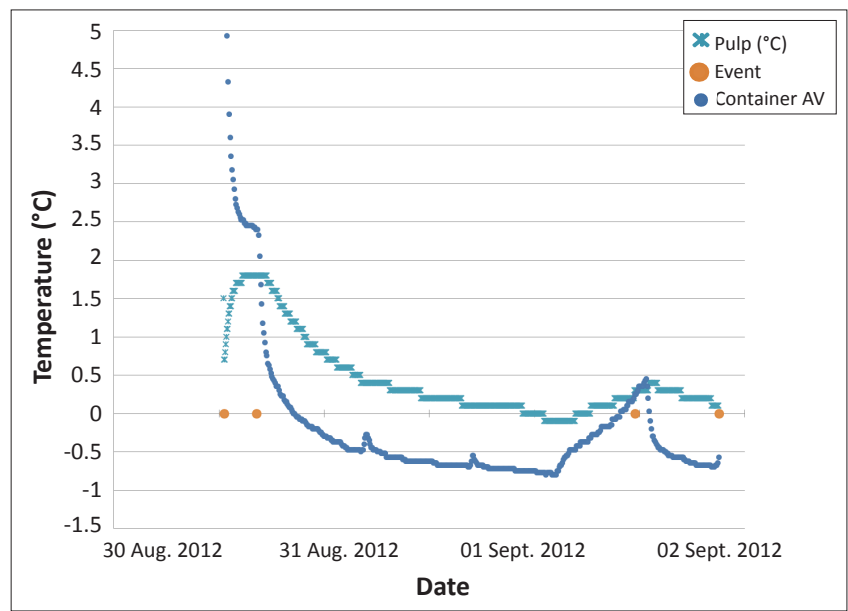

Note: Temperature measured every 12 hours between 30 August 2012 and 02 September 2012.

FIGURE 4: Comparison of average ambient temperature and fruit pulp temperature for apples.

the container decreased to $0.5{ }^{\circ} \mathrm{C}$ within $5 \mathrm{~h}$ and $25 \mathrm{~min}$, whilst the fruit pulp temperature only decreased to $0.5{ }^{\circ} \mathrm{C}$ after $14 \mathrm{~h}$ and $45 \mathrm{~min}$. The average ambient temperature decreased to $-0.5{ }^{\circ} \mathrm{C}$ after $17 \mathrm{~h}$ and $30 \mathrm{~min}$. The lowest fruit pulp temperature recorded during the journey was $-0.3{ }^{\circ} \mathrm{C}$, four days and $16 \mathrm{~h}$ after the fruit was initially loaded into the container.

\section{Conclusion}

The analysis of the historic data revealed two important findings. Firstly, the majority of cold chain breaks were observed in the port segment. Secondly, the data revealed that almost a quarter of all breaks occurred between 12:00 and 15:00, which is also the hottest time of the day.

The trial shipment provided valuable results and highlighted some important issues. The first issue being the variation in 
the ambient temperatures inside the same container, which could potentially have a negative effect on the quality of the fruit and should be a cause of concern. The second issue being the difference between the ambient temperature and the fruit pulp temperature.

The results of the trial made it clear that any break in the cold chain can cause a rise in the fruit pulp temperature. Whilst the average ambient temperature of $-0.147^{\circ} \mathrm{C}$ from the cold store to the vessel is acceptable, the average pulp temperature of $0.489{ }^{\circ} \mathrm{C}$ during the same segment far exceeds the optimum carrying temperature of $-0.500{ }^{\circ} \mathrm{C}$. Unfortunately, exporters might only see what is happening with the ambient temperature throughout the cold chain, whilst they remain unaware of the true impact of cold chain breaks on the fruit pulp temperature itself.

This research adds value to the fruit export industry by identifying the need to improve operational procedures in the cold chain. A more efficient and effective cold chain would improve the ability to maintain the quality of fruit destined for export, reduce losses and thus result in significant savings for both the fruit industry and logistics operators. At the end of the day, it will improve the international competitiveness of the South African fruit industry.

Limitations and difficulties experienced during the research study included a lack of cooperation from the fruit industry and unwillingness to share financial data. A lack of information regarding the extent of the damage, the value of the fruit lost and temperature recordings showing breaks in the cold chain was a major obstacle to research.

Future objectives include the development of a 'Good Cold Chain Practice Guide'; this would state best practice operational procedures from a logistical point of view for each link in the fruit export cold chain. Investigating possible ways to monitor the remaining segments of the fruit export supply chain from the moment when the fruit initially starts to grow in the vineyard or orchard, all the way to where it ends up with the consumer could form the basis of future research.

An integral part of South Africa's fruit export cold chain is human involvement, at least during the foreseeable future. To achieve improvement in the cold chain, all cold chain participants will need to have an increasing awareness of the impact of temperature on fruit quality and shelf life. Studies such as this one are the first step towards achieving this goal.

\section{Acknowledgements Competing interests}

The authors declare that they have no financial or personal relationship(s) that may have inappropriately influenced them in writing this article.

\section{Authors' contributions}

E.v.D. (CSIR) was the project leader. H.F. (Stellenbosch University) was a Masters student in Logistics Management. The study was the topic of his research. L.G-G. (Stellenbosch University) was the supervisor for the research. M.D. (Stellenbosch University) was an advisor for the project and assisted with the design of the trial.

\section{References}

Blakey, R.J., Bower, J.P. \& Bertling, I., 2011, 'Importance of Cold Chain Maintenance and Storage Temperature to Avocado Ripening and Quality', Acta Horticulturae (ISHS) 911, 555-564.

Crisosto, C.H., Smilanick, J.L. \& Dokoozlian, N.K., 2001, 'Table grapes suffer water loss, stem browning during cooling delays', California Agriculture 55(1), 39-42. http:// dx.doi.org/10.3733/ca.v055n01p39

Dodd, M.C., 2012, 'Managing airflow inside reefer containers benefits produce quality', Acta Horticulturae (ISHS), in press.

Dodd, M.C. \& Van Dyk, F.E., 2013, Analysis of temperature breaks in the fresh fruit export cold chain from South Africa, poster made for Post-Harvest Innovation Programme exhibition, Century City.

Kader, A.A., 2005, 'Increasing Food Availability by Reducing Postharvest Losses of Fresh Produce', Acta Horticulturae (ISHS) 682, 2169-2176.

Kruger, A., 2013, Cool Logistics Africa, Presentation delivered at Cool Logistics Africa 2013, 16-18 April, Cape Town.

Maheshwar, C. \& Chanakwa, T.S., 2006, 'Post Harvest Losses due to Gaps in Cold Chain in India - A Solution', Acta Horticulturae (ISHS) 712, 777-784.

Nelson, K.E., 1985, 'Harvesting and handling of California table grapes for market', ANR publications, Bulletin 13, University of California, Division of Agriculture and Natural Resources, Oakland, USA.

Strydom, J., 2010, Report to the Pack House Action Group, viewed 08 October 2012, from http://www.hortgro.co.za/production-techical-information/packhouseaction-group-pag/

The Perishable Product Export Control Board, 2012, HP22 Carrying Temperature Regime - PPECB, viewed 18 June 2013, from http://www.ppecb.com/index.php/ doc_download/101-hp22-carrying-temperature-regime.html

The Perishable Products Export Control Board, 2013, Export Directory 2013, The Perishable Products Export Control Board, Parow.

Thompson, J.F., 2002, 'Storage systems', in A.A. Kader (ed.), Postharvest Technology of Horticulture Crops, Agriculture and Natural Resources, University of California, USA, 113-128.

Thompson, J.F., Rumsey, F.G., Kasmire, R.F. \& Crisosto, C.H., 2008, Commercial Cooling of Fruits, Vegetables and Flowers, University of California, Division Agriculture and Natural Resources, Oakland, USA.

Van Dyk, F.E., 2011, Fruit Industry Case Study, Council for Scientific and Industrial Research, Pretoria. 